Physics Division; in 1951, he went to Corona, California, to serve for two years as director of the then newly established Corona Laboratories. Dr. Huntoon was appointed associate director for physics at the Bureau in 1953, and deputy director in 1958. He was born in Waterloo, Iowa, in 1909, studied at Iowa State Teachers College, and took his Ph.D. degree in experimental nuclear physies at the State University of Iowa in 1938.

\section{Dr. J. C. Schoonover}

Dr. IrL C. Schoonover has for the past five years been an associate director of the National Bureau of Standards, serving as principal staff adviser to the director on programme development, co-ordination and evaluation. Dr. Schoonover's thirty-year association with the Bureau has included the organization and direction of basic research programmes in the properties of materials, particularly at extremely high temperatures. $\mathrm{He}$ is well known for his direction of a research programme on dental materials, and was a pioneer in research on polymer structure at the Bureau. His work and leadership provided an integrated approach to studies of the chemical and physical properties of long-chain molecules in relation to structure. Dr. Schoonover received the Department of Commerce Superior Accomplishment Award in 1946 for his work on refractory materials, undertaken during his secondment to Los Alamos, and in 1961 he was awarded the Department of Commerce Gold Medal for Exceptional Service, being cited for "extraordinary versatility as a seientist-executive, and ... exceptional leadership". Dr. Schoonover was born in Belington, West Virginia, and studied at Davis and Elkins College and George Washington University. $\mathrm{He}$ gained M.A. and Ph.D. degrees from Princeton University.

\section{Dr. A. T. McPherson}

Dr. A. T. McPherson has been associate director of the Office of Technical Services of the Department of Commerce for the past sixteen months. He worked there with Government agencies and national standards organizations in developing a new programme of interAmerican co-operation on standards. Prior to this, Dr. McPherson had for ten years been an associate director of the National Bureau of Standards, co-ordinating committee activities on codes and specifications, and directing calibration and testing services throughout the Bureau. His investigations at the Bureau have included work in the fields of gas chemistry, electrical insulation, natural and synthetic rubber, and high polymers. From 1943 until 1951 he was chief of the Organic and Fibrous Materials Division, when the major part of his own scientific work was concentrated on rubber research. During the Second World War he served as a technical adviser on the Rubber Survey Committee, and was instrumental in the application of numerous new techniques in the making of both natural and synthetic rubbers. Dr. McPherson was born in Marceline, Missouri, and studied at Trinity University and the University of Texas. He was awarded a Ph.D. in chemistry by the University of Chicago in 1923.

\section{R. B. Scott}

Russell B. Scott has for the past ten months served as acting director of the Boulder Laboratories (Colorado) of the National Bureau of Standards. He was chief of the Cryogenic Engineering Laboratory at Boulder from its establishment in 1954 until his appointment as acting director. The Cryogenic Laboratory is one of three which comprise the National Bureau of Standards Laboratories at Boulder, the others being the Central Radio Propagation Laboratory and the Radio Standards Laboratory. Mr. Scott is a veteran of thirty-five years service in the cryogenic field with the Bureau, beginning with a post

in the low-temperature section in Washington Laboratories in 1928. During the Second World War he was involved in the work of determining properties of uranium compounds, in support of the Manhattan Project. In 1948 he was appointed chief of the Cryogenic Physics Section in Washington. Mr. Scott was born in Ludlow, Kentucky, in 1902, and studied at the University of Cincinnati and the University of Kentucky. He was awarded an M.S. degree in physies by the University of Kentucky in 1928.

\title{
Research Contracts Awarded by the International Atomic Energy Agency
}

THE two-hundredth research contract awarded by the International Atomic Energy Agency since this programme, intended to promote the peaceful uses of nuclear energy, began in 1958, was recently given to the Lovanium University at Leopoldville, Congo. In addition, 165 contracts were renewed during that period. The cost of the programme so far amounts to 2,923,035 dollars $(1,770,469$ dollars for the original 200 contracts and $1,152,566$ dollars for 162 renewals). Out of this total $2,447,292$ dollars were paid out of the Agency's own funds and 475,743 dollars were provided by the United States under an agreement concluded in 1960 between the Agency and the United States Atomic Energy Commission. The following is a breakdown of research contracts awarded by the Agency:

Subject category

Radioactive waste management and environmental research Health physies and radiation protection Radiobiology Safeguards method Investigations involving the use of reactors Radioisotope applications in agriculture Radioisotope applications in hydrology Radioisotope application in medicin Miscellaneous Total

The research to be carried out in Leopoldville at the $T R I C O$ reactor Centre should help to elucidate various affections of bone frequently found in inhabitants of that region, and caused by leprosy, smallpox and other diseases or by nutritional deficiencies. The Agency will provide radioisotopes as well as various other supplies and equipment worth 7,750 dollars.

\section{Science in Sixth-form General Education}

PART 2 of the Science and Education Report Science in Sixth-Form General Education, issued by the Association for Science Education, complements the Policy Statement previously issued by outlining the proposals of the Panel for courses which aim to give some understanding of the methods of science and appreciation of the effects of science on everyday life (Pp. 62. London: John Murray. Published for the Association for Science Education, 1963. $2 s$. net). Besides indicating the general principles of such courses, the Report presents detailed suggestions for courses on the nature of scientific thought; cosmology; energy; matter; life; behaviour; environment; and science and society. They are not intended to provide a syllabus to be studied in full, but rather to offer a broad field of suggestions which may assist teachers to devise their own courses. For the first course, for example, a historical and methodological approach and a logical and philosophical approach are outlined, with adequate bibliographies, and these bibliographies are frequently supplemented by lists of film-strips and films. The Report is intended to be read in conjunction with the Policy Statement and with the other three sections of Part 1, dealing with physies, biology and chemistry, respectively, for grammar schools. It is an admirable piece of work on 